\title{
SUBMARINE TOPOGRAPHY, SURFICIAL GEOLOGY, AND FAUNA OF OCEANOGRAPHER CANYON, NORTHERN PART
}

\author{
By \\ Page C. Valentine, U.S. Geological Survey \\ and \\ Joseph R. Uzmann and Richard A. Cooper, National Marine Fisheries Service
}

1984

\section{INTRODUCTION}

Oceanographer Canyon has been investigated by the National Marine Fisheries Service (NMFS) and the U.S. Geological Survey (USGS) since 1974 in a series of dives with research submersibles. The objectives of the long-term study are to describe the canyon fauna, to document the distribution, abundance, and substrate dependence of benthic invertebrates and demersal fishes, to describe the surficial geology, including unconsolidated sediment and outcropping rocks, and to study sedimentary features and erosional processes. A synthesis of our observations as of the 1978 field season has been published (Valentine and others, 1980a).

Recently, oil and gas exploration on Georges Bank and the proposed leasing of the Continental Slope have prompted studies to assess and monitor the biological and geological environment of the shelf and canyons, and in 1980 the NMFS established several permanent stations on Georges Bank and in Oceanographer Canyon that are visited annually (fig. 1). Since 1978, we have continued our observations in Oceanographer Canyon with the submersibles Alvin (1980, 1982) and Johnson-Sea-Link (1981, 1982, 1983). During these cruises, we made a new bathymetric survey of the northern part of the canyon using a 12 $\mathrm{kHz}$ echo sounder that is the basis for the map presented here. Navigation was based on Loran-C time-delays (9960 chain) with fixes taken 1 to 5 minutes apart using a Northstar $6000^{1}$ loran receiver. The survey lines are spaced $500 \mathrm{~m}$ or less apart, and profiling is most dense in the canyon head ano on the east rim. Latitude and longitude on our map are based on Northstar 6000 conversions at sea and are therefore approximate. We find that accurate, large-scale $(1: 6,000)$ navigation and bathymetric charts are essential for conducting our submersible operations and for interpreting our observations. The maps presented here have been reduced for publication.

Observations from the submersibles were documented by voice tapes and by hand-held and externally mounted photographic and video cameras. Sediment samples were collected with devices operated by mechanical arms, which included a jawlike grab sampler, a canvas bag sampler attached to a metal frame that was scraped across the sea floor, and core tubes. Sediment size analyses of samples from Oceanographer Canyon and NMFS stations 2 and 3 and

${ }^{1}$ Use of trade names is for descriptive purposes only and does not constitute endorsement by the U.S. Geological Survey.
Block 312 (fig. 1, table 1) were performed using a rapid sediment analyzer (Schlee, 1966) for the sand fraction and a Coulter Counter Model TA $I^{1}$ for the silt and clay fractions. Shelf, lower slope, and upper rise sediments reported on by earlier studies (USGS stations) were processed using a rapid sediment analyzer for sand and pipette analysis for silt and clay (Hathaway 1971; Schlee, 1973). The gravel-size fraction in all samples was determined by sieving. Statistical parameters of grain size were calculated using the formulas of Folk (1980), including the graphic mean $\left(\mathrm{M}_{\mathrm{z}}\right)$ the inclusive graphic standard deviation $\left(\sigma_{\mathrm{I}}\right)$, the inclusive graphic skewness $\left(\mathrm{Sk}_{\mathrm{I}}\right)$, and the graphic kurtosis $\left(\mathrm{K}_{\mathrm{G}}\right)$; phi values were obtained from cumulative curves (weight percent) plotted on probability paper.

Our purposes in this study are (1) to describe the submarine topography based on our new bathymetric survey; (2) to describe and map the bottom types and sedimentary features and processes in the canyon, and to compare the canyon sediments to those from the surrounding shelf and slope environments; and (3) to identify the benthic invertebrates and demersal fishes that characterize particular substrates and depth intervals.

The cruises to Oceanographer Canyon since 1974 were sponsored by the U.S. National Oceanographic and Atmospheric Administration (NOAA), Manned Undersea Science and Technology Office. We gratefully acknowledge the support of the crew of the Johnson-Sea-Link and support ship RV Johnson, Harbor Branch Foundation; the crew of the Alvin and support ship RV Lulu, Woods Hole Oceanographic Institution; and the crew of the Nekton Gamma and support ship Atlantic Twin, General Oceanographics, Inc. We also thank Maura Connor, Leslie Reynolds, Donald McElroy, Lawrence Poppe, Dann Blackwood, Patricia Forrestel, and Jeffrey Zwinakis for their technical assistance.

\section{SUBMARINE TOPOGRAPHY}

Oceanographer Canyon is the largest submarine canyon on the southeastern edge of Georges Bank (fig. 1). The canyon's path is sinuous; it incises the shelf for some $22 \mathrm{~km}$, and from its complexly dissected head in the north, it crosses the shelf in two large meanders. This study is focused on the northern $15 \mathrm{~km}$ of the canyon, from about $40^{\circ} 24^{\prime}$ to $40^{\circ} 30^{\prime} \mathrm{N}$ (sheet 2). Eleven 
cross sections drawn at true scale (sheet 1) reveal the broad, shallow nature of the canyon in this region; it increases in width from $2.7 \mathrm{~km}$ in the head to $5.5 \mathrm{~km}$ in the south, and in depth from 210 to $700 \mathrm{~m}$. The canyon floor, where sand and dunes are present (sheet 3 ), is only 100 to $300 \mathrm{~m}$ wide. The slope of the thalweg is very gentle throughout this part of the canyon varying from 1 to $1.5^{\circ}$; at its steepest, it slopes $3^{\circ}$ in the western arm of the canyon head and in the meander. The large meander extends from about $40^{\circ} 28^{\prime}$ to the base of the r..ap, and the steepest walls are present between $40^{\circ} 24$ ' N and $40^{\circ} 25^{\prime} \mathrm{N}$ on the eastern wall (section $1-\mathrm{l}^{\prime}$ on sheets 1 and 3 ). North of $40^{\circ} 28^{\prime} \mathrm{N}$, the canyon swings to the north for a short distance and then turns sharply to the west.

The canyon head is more complex morphologically than the main canyon. There are six major valleys draining into it from the surrounding shelf, and they are best developed in the western arm of the canyon head. The steepest and narrowest valley enters from the southwest, and it extends all the way to the canyon floor (sections $b-b^{\prime}$ and $c-c^{\prime}$ on sheets 1 and 3 ). The western valley, at the termination of the canyon, is subcircular and appears to drain a large area from the south, west, and north. The northern and southern walls of the canyon at the mouth of this valley are steep, and although the average inclination of the southern wall is about $38^{\circ}$ (section $a-a^{\prime}$ on sheets 1 and 3 ), it is almost vertical in some places. The walls are armored with talus blocks that have been eroded from a resistant siltstone layer that crops out at about $150 \mathrm{~m}$; the siltstone retards erosion and is responsible for the steepness of the walls. In the western valley, the siltstone has been breached. A broad, gently sloping valley floor that is covered with sand leads out of the canyon to the shelf, and only a small exposure of dislocated siltstone blocks was observed at $143 \mathrm{~m}$ (dive 16 on sheet 3 ). In contrast, the southwestern valley is much narrower, and its development is constrained by the resistant layer on the canyon rim. The valley profile (section $c-c^{\prime}$ on sheets 1 and 3) flattens between 155 and $160 \mathrm{~m}$ where a steep outcrop of burrowed, semiconsolidated silt is capped by siltstone outcrop and talus (dive 14). Above this level, the head of the valley terminates at a steep wall of silt that is, in part, bioeroded and collapsed.

On the northern side of the canyon head, a broad, shallow valley resembles a terrace, and it remains wide in its steeper lower part where it reaches the canyon floor. The western side of this valley abuts a promontory held up by the resistant siltstone. Siltstone talus blocks are not present where dives 20 and 21 traversed the lower part of the valley; the siltstone may have been breached long ago and all talus subsequently eroded, or the strata that represent the resistant layer may not have been lithified where this valley developed. The three valleys on the northeastern and eastern sides of the canyon head incise the shelf to approximately the same depth as the other valleys, but they do not extend below about $200 \mathrm{~m}$ and do not reach the canyon floor.

There are no prominent tributaries on the walls south of the canyon head in the area under study. The bathymetric survey grid is tight enough to identify features of the same magnitude as the valley that enters the canyon head from the southwest (section $b-b^{\prime}$ on sheets 1 and 3). Moreover, the several bathymetric tracks along the canyon walls do not reveal small valley-like features. We have not observed gullies, ravines, or small valleys on the canyon walls during our dives; however, our traverses have been up the walls rather than along them and thus not designed to search for such features.

The canyon walls display a gently undulatory character. Depressions, or valleys, are broad and shallow, and quite of ten do not extend from the shelf break to the canyon floor. The walls generally vary in slope from 5 to $20^{\circ}$. The western canyon wall attains slopes of 15 to $20^{\circ}$ and generally is less steep than the east wall where maximum slopes reach 20 to $38^{\circ}$. The steepest part of the east wall in the northern part of the canyon is in a large meander (section $1-\mathrm{l}^{\prime}$ and dive 25 on sheets 1 and 3 ). Here the east wall, from its base to about $500 \mathrm{~m}$, is covered by dislocated, angular blocks of semi-consolidated silt that measure up to $4 \mathrm{~m}$ across. Above the talus, a series of subvertical cliffs and spalled blocks of silt, separated by narrow ledges and overhangs, extends up to $375 \mathrm{~m}$ where the slope decreases and mass-wasting is less spectacular.

South of the canyon head, the shelf steepens markedly into the canyon at approximately 150 to 170 $\mathrm{m}$. We speculate that this feature may delineate a resistant, partially eroded siltstone stratum similar to the beds that crop out at $150 \mathrm{~m}$ in the western arm of the canyon head.

\section{SEDIMENT TEXTURE AND DISTRIBUTION}

Our observations reveal the presence of seven major bottom types in northern Oceanographer Canyon and on the adjacent Continental Shelf (sheets 3 and 4). The shelf around the canyon is covered with (1) quartzose sand. At the shelf break, the sediment texture changes abruptly to (2) pebbly sands and gravel and (3) gravel pavements that lie in a band along the canyon rim. The canyon is underlain by (4) a semiconsolidated sandy silt or mud. On the canyon walls, the silt is covered intermittently by a thin veneer of (5) rippled sand; and (6) large dune-like features of sand up to $3 \mathrm{~m}$ high lie on the canyon floor. In the western arm of the canyon head, (7) siltstone outcrops and talus are present on the canyon rim and walls; and similar talus is commonly present at the base of the canyon walls.

Broad areas of the sea floor within the canyon are characterized by one of these sedimentary facies, but since most of the canyon sediments are unconsolidated and mobile, the character of the sea floor, particularly the canyon walls, is changing constantly. The sediments in the canyon and its environs move in response to a complex current regime (Folger and others, 1978; Valentine and others, 1980a; Twichell and others, 1981; Butman and others, 1982). A welldefined drift circulates clockwise around Georges Bank, traversing Oceanographer Canyon from the northeast; and tidal currents are alined approximately parallel to the axis. These currents, and probably internal waves and storm-generated currents, are responsible for transporting shelf sediments into the canyon and reworking them once they reach the canyon floor. Most investigators consider that the sediments found on Georges Bank and in the canyons were derived from glacial outwash during the Pleistocene and that Georges Bank is now effectively isolated from terrestrial sediment sources by the Gulf of Maine (Stetson, 1949; Schlee, 1973; Valentine and others, 1980a). 
Our visual observations and size analyses of 82 sediment samples collected by submersibles are the basis for delineating the sedimentary environments of the northern part of the canyon (sheets 3,4 and table 1). An additional 57 samples from the region are included for comparative purposes (fig. 1 and table 1); three were collected by submersible from the walls deep in the canyon, and seventeen samples were collected by submersible from three stations on the shelf (NMFS 2 and 3, and Block 312). All the other samples Nere collected by grab samplers from surface ships; they include 28 from the shelf, slope and rise adjacent to Oceanographer and Lydonia Canyons, eight from the shelf south of Marthas Vineyard and one from the head of Oceanographer Canyon (Hathaway, 1971; Schlee, 1973).

\section{Shelf Sand}

The shelf on the southeast flank of Georges Bank is covered by fine to medium quartzose sand (Schlee, 1973). We collected only two samples of shelf sand during our dives in Oceanographer Canyon, but size analyses of samples collected by submersible from NMFS 2 and 3 and Block 312 on the shelf to the east are useful in characterizing the shelf sands and in confirming the results of previous studies.

Six closely-spaced samples from a $0.1-\mathrm{km}^{2}$ area north of Powell Canyon (samples 51-56, NMFS station 2) consist of slightly granular, medium to fine sand, moderately to poorly sorted, fine-skewed, and mesokurtic to very leptokurtic; the mud size fraction in these samples ranges from 2.84 to 5.58 percent by weight. Six samples from an area of similar size located north of Lydonia Canyon (samples 42-47, NMFS station 3) consist of slightly granular, medium to coarse sand, moderately well sorted, nearly symmetrical, and mesokurtic. They are cleaner than the sands at NMFS 2, containing only 1.08 to 1.20 percent mud. The sediments at Block 312 were sampled in 1982 near a recently abandoned drill site (samples 158-162) and they contain 0.92 to 1.18 percent mud, similar to the sands at the adjacent NMFS station 3 . However, the Block 312 sediments contain up to 2.85 percent gravel, which is generally higher than at NMFS 3 and reflects the addition of rock cuttings during drilling.

The sediments from NMFS stations 2 and 3 and Block 312 resemble the sands around Oceanographer and Lydonia Canyons that were analyzed by Schlee (1973). Cumulative probability curves were plotted for 14 of Schlee's shelf samples (samples 31-41 and 48-50) using the original size analyses (Hathaway, 1971). These sediments are medium to very fine sand, moderately to well sorted, and mesokurtic to very leptokurtic. They and the samples from NMFS station 2 and 3 and Block 312 plot as a cluster of points delineating an area representative of shelf sands in this region (fig. 2). Shelf sands vary in texture locally, but in general they constitute a broad, fairly homogeneous sheet. In northern Oceanographer Canyon, the shelf sand appears to be restricted to depths less than $150 \mathrm{~m}$.

The surface morphology of the sand deposits at Oceanographer Canyon and at our stations on the shelf is generally hummocky or rippled (figs. 3 and 4). Hummocky surfaces result from the scouring activities of fish and scallops which form shallow depressions in the sand up to 10-15 $\mathrm{cm}$ deep. Ripples are produced by the active current regime on the bank. These features are ephemeral and attest to the mobility of the sands. The shelf sand is the principal external source of sediment for the canyons, and as the sands enter and move through the canyon, they form new associations with canyon sediments that are less mobile.

\section{Pebbly Sand, Gravel, and Gravel Pavement}

At the canyon rim, the sediment texture changes over a short distance from sand to pebbly sand and gravel (sheet 3 and figs. 5-7). Gravel particles ranging from granule to boulder size cover up to 50 percent of the bottom at the shelf break and on the upper part of the west wall. Elsewhere, gravel particles are sparsely scattered on the canyon walls, and local concentrations are present in the canyon head (sheet 3). In some areas, especially on the east wall, the gravel concentration is greater than 50 percent and a pebble and cobble pavement that includes large boulders (figs. 8 and 9 ) is present at the shelf break and extends part of the way down the wall. Gravel pavements to date have been observed on the upper part of the north wall in the canyon head (dives 17-19), and in coarser aggregations along the east rim and upper wall. None of the dives on the west wall encountered gravel pavements, although they did reveal gravel and pebbly sand. The observations of pavement-covered bottom on the east wall indicate that the tightly packed gravel covers an extensive area along the canyon rim; and this inference is supported by the interpretations of a side-scan survey in that area (David Twichell, USGS, personal commun., 1982). We previously have interpreted the gravel, particularly in the pavement areas, to be ice-rafted and of glacial origin, deposited during a period of lower sea level (Valentine and others, 1980a).

Samples collected from gravelly areas are (1) sandy pebble gravels, very poorly sorted, coarse skewed and very platykurtic, and (2) pebbly coarse to medium sand, very poorly sorted, coarse skewed, and platykurtic (fig. 2 and sheet 3 ). These gravels and pebbly sands are actually coarser than the analyses reveal because the largest clasts were not collected by the sampling apparatus.

Gravel and pebbly sand samples display a distinctive sedimentary character. They are coarser and much more poorly sorted than the shelf sands; they are also platykurtic or polymodal, which results from mixing as shelf sands move through the stationary gravel deposits located on the canyon rim. The sand is commonly rippled in areas where the gravel is not closely packed. Within the gravel pavements there is no room for ripples to form, but sandy lag deposits in the lee of cobbles and boulders (fig. 9) are evidence that shelf sands are moving into the canyon through the gravel, although in volumes insufficient to bury the gravel (Valentine and others, 1980a).

\section{Siltstone Outcrops and Talus}

Outcrops and talus of siltstone dominate the western arm of the canyon head and are responsible for the steep slope of the north and south canyon walls there (sheet 3 and figs. 10-15). Fragmented blocks are present in place along the 150-meter isobath at the shelf break, and the canyon walls immediately below are covered with broken slabs up to a meter long. 
Lower on the walls, the siltstone talus is composed of rounded boulders that have been extensively eroded by boring organisms. The rock surfaces are oxidized to orange-brown (samples 166-168), and rocks of similar external appearance were collected on the lower part of the east wall (samples 164 and 165). They are dolomitic quartz siltstone, gray on freshly broken surfaces; microfossils are not present, but they do contain poorly preserved specimens that resemble Hiatella arctica, a modern infaunal bivalve that inhabits mar.ne environments ranging from intertidal to $366 \mathrm{~m}$ in the northwest Atlantic (Roger Theroux, NMFS, personal commun., 1982). These rocks appear to be an indurated form of the Quaternary sandy silt that is exposed on the canyon walls. Dolomitic siltstones have been reported from Georges Bank and from many submarine canyons on the Atlantic margin by Deuser (1970), who postulated that magnesium-rich solutions could have formed by evaporation in shallow lagoons on the outer shelf during periods of lowered sea level.

\section{Canyon-Wall Sand}

On the canyon walls below the gravelly rim, there are thin, mobile sand sheets, often rippled, that overlie a semiconsolidated sandy silt substratum (sheet 3 and figs. 16-23). Samples 115,121 , and 122 contain the lowest concentration of fines ( 0.03 to 0.07 percent) and were collected from dune crests in the western valley of the canyon head where little burrowing is taking place; whereas samples 23 and 150 contain the highest concentration of fines (21.06 and 27.21 percent) and were collected from areas where semiconsolidated sandy silt underlies a thin veneer of sand. The sand sheet appears to be continuous in the area surveyed on the west wall, but its distribution is patchy in other areas. Sediments from the west wall (sheet 3 and samples 23-26) are slightly granular, silty, medium to very fine sand, very well sorted to poorly sorted, fine-skewed, and leptokurtic to very leptokurtic.

The sediments found on the canyon walls are really shelf sands that have migrated across the gravelly rim, and they plot within or very near the field outlined by shelf sands (fig. 2). The chief difference is the addition of silt and clay, which constitutes 0.03 to 27.21 percent by weight of the sample and is derived from the burrowing activities of organisms into the sandy silt substratum. The variation in silt and clay content in canyon-wall sand is the cause of the wide range in sorting of these former shelf sands.

Sand deposits on the canyon walls are often rippled, and in several areas on the west wall and in the canyon head (sheet 3 , dives $3,4,5,7,16$, and 28) the mobile sands have been formed into dunes that resemble features present on the canyon floor that are discussed below. The dunes on the lower west wall are up to a meter in height (figs. 22 and 23); their steep sides face obliquely downcanyon, and their crests are aligned approximately northeast-southwest. This deposit is situated in a broad side valley, and it appears to be a buildup of the sand that migrates along and down the canyon walls. The dunes are apparently moving obliquely down the wall toward the axis. In the western valley of the canyon head, the dunes are alined north-south with their steep sides facing into the canyon; the sand is migrating from the adjacent shelf down the wall into the canyon head. We have also observed much smaller deposits of duned sand on the east wall (dive $12,159 \mathrm{~m}$; dive 24,375 to $296 \mathrm{~m}$ ).

\section{Sandy Silt Substratum}

The canyon walls and axis are underlain by a semiconsolidated sandy silt or mud of undetermined thickness that contains calcareous nannofossils of Quaternary age (sheets 3 and figs. 24-29). Most samples of this sediment type are sandy silt, but some samples contain appreciable amounts of clay and can be termed sandy mud or mud. The semiconsolidated silt is the predominant bottom type on the lower part of the walls, but on the upper walls it is usually covered by sand and gravel. Sediment covering the silt ranges in thickness from several centimeters on the upper walls to several meters on the canyon floor where duned sand is present. In contrast to the unconsolidated sands in the canyon, the sandy silt is firm; it is a good medium for burrowing by organisms in search of food and shelter. The products of bioerosion range in size from unconsolidated silt and clay particles to pebble-size pieces of silt substratum. Burrows are common, and in some areas the bottom is riddled with them; close-packed burrows, or "pueblo villages", usually harbor a wide variety of fish and crustaceans. Pueblo village structures also weaken the sea floor and commonly result in local mass-wasting on a small scale. Steep outcrops of silt are formed where material has fallen away, and blocks of cobble to small boulder size are scattered on the wall below (fig. 29). Burrows are uncommon where the silt is wholly or partly covered by sand.

Fifteen samples were analyzed, including fragments of burrowed semiconsolidated silt found in sand on the canyon floor (sheet 3 and table 1). The samples are predominantly sandy silt or mud and are poorly to very poorly sorted, mostly fine-skewed, and mesokurtic to very platykurtic. The sediment is much finer grained than any other sediment found in the canyon or on the adjacent shelf (fig. 2). The fine grain size, very poor sorting, and platykurtic nature of the sandy silt all suggest that it was deposited from suspension. The source of these sediments probably was glacial outwash during times when Pleistocene glacial ice occupied the Gulf of Maine and sea level was lower than it is today (Stetson, 1949; Valentine and others, 1980a).

We have not observed modern fine-grained deposits in the northern part of the canyon. At present, the flux of sediment from the continent to the North Atlantic shelf is very small because runoff is low relative to times when glaciers were present on the margin; flooded valleys are now estuaries that act as sediment traps, and Georges Bank and its canyons are isolated from the mainland by the Gulf of Maine. It appears that unconsolidated fine sediments within the canyon are the product of local erosion, primarily by organisms; these sediments are mobile, and they are transported out of this part of the canyon by currents.

A comparison of mean grain size, sorting, and kurtosis parameters indicates that the semiconsolidated silt exposed on the canyon walls and on the canyon floor is similar to modern slope and rise sediments (figs. 1 and 2). The statistical parameters presented here for the slope and rise samples were derived from size analyses of previous studies (Hathaway, 1971; Schlee, 1973). The range of mean 
grain size of the canyon samples encompasses most of the modern slope and rise sediments, although several samples from the lower slope are somewhat finer grained. Sorting is very poor in both sample groups, and the canyon silt is generally more platykurtic. Georges Bank and the northern part of Oceanographer Canyon are areas where vigorous currents are reworking relict sediments and where contemporary deposition is not occurring, except perhaps for the sand on the canyon floor. The shelf sands contain a small ar ount of silt and clay. Fine sediment, probably derived from the reworking of the shelf sands and from bioerosion of the canyon walls, is being deposited on the Continental Slope and Rise where currents are apparently weaker than on the Shelf or in the upper reaches of the canyons. The modern slope and rise sediments are texturally analogous to the Quaternary canyon silt, but their provenance and environment of deposition probably have been quite different.

There is also a deposit of silt on the sanddominated shelf off Marthas Vineyard (Schlee, 1973). These fine-grained sediments (fig. 1, samples 71-78) apparently are derived by winnowing from Georges Bank sands and transported westward in suspension to the area south of Marthas Vineyard, where currents are weaker and deposition occurs (Bothner and others, 1981; Twichell and others, 1981). The sediments are sandy silt and mud, and they are comparable texturally to the fine-grained canyon, slope, and rise sediments (fig. 2) in that they display a similar range of sorting and kurtosis. However, they are less variable in their mean grain size and are dominated by a mode at 5 phi; and they differ in their provenance and depositional environment from the canyon, slope, and rise silts.

In summary, texturally similar silt-size sedimentary deposits are present in three distinct regions of the margin: (1) semiconsolidated Quaternary silt is exposed on the canyon walls and on the canyon floor and was presumably derived from glacial outwash; (2) unconsolidated silt on the slope and rise is probably a modern product of both the winnowing of shelf sands and bioerosion of canyon walls; and (3) unconsolidated silt concentrated on the shelf south of Martha's Vineyard appears to have accumulated from particles winnowed from Georges Bank sands and transported westward by the prevailing currents.

\section{Canyon-Floor Sand}

The canyon floor is underlain by sandy silt that is covered with large, asymmetrical dune-like features formed of sand that attain heights of $3 \mathrm{~m}$ and lengths of $15 \mathrm{~m}$ between crests (sheet 3 and figs. 30-38). In the main axis, south of the canyon head, the sinuous crests of these dunes are alined across the axis, and the features are asymmetrical either up- or downcanyon. The gentle dune slopes are heavily rippled parallel to the dune crest. In contrast, the steep faces of the dunes are often rippled normal to the crest, and the sandy silt substratum is commonly exposed in the dune troughs. Dunes also cover the floor in the canyon head. They are also asymmetrical, with their steep sides generally to the west, but at about $260 \mathrm{~m}$ in the thalweg (sheet 3, between samples 11 and 12) they change orientation and become asymmetrical to the east. Sand dunes disappear in the western arm at about $220 \mathrm{~m}$ where the lower walls are covered with talus blocks (dive 15). However, a side-scan survey of this part of the canyon head showed that bedforms resembling sand dunes or megaripples are present somewhat to the west and extend in a band westward up the canyon wall to the shelf break (David Twichell, USGS, personal commun., 1982). This interpretation subsequently was confirmed by observations from a submersible (dive 16).

Sands from the canyon floor were sampled at seventeen locations (sheet 3 and table 1). They are granular to slightly granular coarse to medium sand, moderately to poorly sorted, near-symmetrical to fine skewed, and leptokurtic to very leptokurtic. The canyon-floor sands are derived from the shelf; they have been transported through the gravel deposits on the canyon rim and down into the canyon across the silt substratum on the walls. Their mean grain size falls within the range displayed by the shelf sands (fig. $2)$, but they are somewhat coarser than sands from the canyon walls because their silt and clay content is generally lower.

As the shelf sands move into the canyon, they enter a sedimentary environment that is influenced by outcropping semiconsolidated sandy silt, the chief constituent of the canyon walls. The burrowing of benthic organisms and demersal fish erodes the silt and causes it to be mixed with the mobile sand layer. Thus, the silt and clay content of the wall sands increases. The canyon-floor sands contain granules and small pebbles of semiconsolidated silt that are fragments of burrow walls (fig. 2, samples 15 and 17); they are evidence both of bioerosion and the mixing of sediments from different sources that occur on the canyon walls. When the sands finally reach the canyon floor, they are winnowed by the currents that produce the dunes. Unconsolidated silt and clay is removed, and the mean grain size shifts to the coarse end of the spectrum (fig. 2). The dunes create a number of sedimentary environments, and the wide range of sorting and kurtosis values for the sands reflects variation in sediment textures found on the crests, in the troughs, and on the stoss and lee slopes of the dunes.

\section{FAUNAL ASSEMBLAGES AND SUBSTRATES}

Benthic assemblages in Oceanographer Canyon, as elsewhere in the marine ecosystem, vary in composition according to temperature, depth, food supply, and the availability of preferred bottom types. The dominant components of the megabenthos and demersal fish fauna exhibit occurrence patterns that suggest that certain species groups are zoned according to substrate, depth, and temperature.

In previous reports on Oceanographer Canyon (Valentine and others, $1980 \mathrm{a}$, b), we documented the presence and relative abundance of 44 megabenthic taxa that were observed more or less commonly on 14 submersible dive transects over a composite depth range of $100-1,900 \mathrm{~m}$. Along the transects, 25 species predominated over the entire depth range, with peak abundances of each generally confined to one of three faunal depth intervals, a shallow zone (100-299 $\mathrm{m})$, a middle zone $(300-1,099 \mathrm{~m})$, and a deep zone $(1,100-$ $1,900 \mathrm{~m}$ ).A re-examination of data from 1978 and earlier (Valentine and others, $1980 \mathrm{a}$, b) and the integration of observations from $1980,1981,1982$, and 1983 dives provides a more coherent view of the relationships between commonly occurring species and substrate type (table 2). The deep faunal zone is not present in the study area. 
The shelf sand surrounding the canyon typically supports starfishes of the genera Asterias, Leptasterias and Coronaster, Jonah crabs and lobsters in shallow subcircular excavations, and gulf stream flounders, four spot flounders, goosefish, red and silver hakes (figs. 3 and 4) and an occasional burrowing anemone (Cerianthus). Bivalves include live scallops in circular depressions and disarticulated shells of the infaunal ocean quahog. The starfishes, red hakes, and bivalves often are present in aggregations, but the other species are solitary. Total biomass of the megabenthos in a unit area is largely weighted by the starfishes, jonah crabs, lobsters, and goosefish.

On the canyon rim and upper walls, a thin layer of poorly sorted pebbly sands and gravels, including occasional boulders, overlies semiconsolidated sandy silt and provides numerous microhabitats (figs. 5-7). This heterogeneous bottom supports a large variety of megabenthos, including burrowers, nestlers and sessile forms. Dominant burrowing organisms include the lobster, jonah crab, conger eel, ocean pout, and tilefish; the majority of individuals usually are observed beneath or alongside glacial boulders ranging up to two meters in diameter. Burrowing anemones are generally sparsely distributed, but they are evidence of firm sandy silt immediately beneath the veneer of pebbly sands and gravels (fig. 5). Gravel pavements are more difficult to burrow because of the tight aggregation of pebbles and cobbles, and they support populations of sessile forms such as the monaxonid sponge, the anemones Actinauge, Actinoscyphia, and Bolocera, and the mobile pencil urchin Cidaris (figs. 8 and 9). Taken collectively, the pebbly sand, gravel, and gravel pavement environments provide a habitat for one of the largest arrays of species in the canyon.

Siltstone outcrops and talus form a biologically rich substrate that is present on the north and south walls of the western arm of the canyon head. Interstices between the fragmented siltstone blocks provide ideal habitat for large populations of white hake, ocean pout, tilefish, codfish, and jonah crabs (figs. 10-14). Large aggregations of the sessile anemones Actinauge and Bolocera are present, and basket stars are common on talus on the canyon walls (fig. 15). The megabenthic biomass is greater per unit area than elsewhere in the northern part of the canyon (Cooper and others, 1983).

The mobile sand sheet that is characteristic of broad areas of the upper canyon walls is underlain by semiconsolidated sandy silt (figs. 16-23). The veneer of canyon wall sand supports a variety of species including flounders, hakes, goosefish, and jonah crabs (fig. 17). Burrowing activity by the megabenthos is confined to areas where the sand layer is relatively thin. Both jonah crabs and lobsters may excavate beneath the sand layer to produce burrows and grottoes in the stiff silt (fig. 20); these excavations may be occupied and enlarged by fishes, particularly red and white hakes. Conical mounds with a central opening are present on the sea floor and presumably mark the burrows of infaunal annelid worms that extend into the sandy silt substratum (fig. 19). Solitary individuals and aggregations of the burrowing anemone (Cerianthus borealis) also indicate areas where the sand sheet is thin (fig. 18); the anemone tubes protrude from the sea floor and provide shelter to a number of other species, expecially black bellied rosefish, redfish, and juveniles of red and silver hakes (fig. 5).
The semiconsolidated sandy silt or mud is present throughout the canyon, but its continuity is masked in some areas, notably on the canyon floor and upper canyon walls, by a variable thickness of sand and gravel. Where exposed, the sandy silt provides a stable sedimentary environment that is attractive to burrowing organisms (figs. 24-29). Lobsters, jonah crabs, munid crabs, and tilefish are especially abundant in closely spaced burrows that are termed pueblo villages (figs. 28 and 29). The burrowing anemone is a typical inhabitant of the sandy silt substrate. Both tilefish and burrowing anemones are restricted to the upper depth zone. Although lobsters and jonah crabs extend into the middle depth zone,they are rapidly replaced by red crabs below $300 \mathrm{~m}$ and virtually disappear below $400 \mathrm{~m}$, where the red crab is the dominant crustacean in terms of biomass. The sessile anemones Actinauge and Bolocera are present in both the shallow and middle depth zones where isolated cobbles and boulders of talus and glacial debris provide the needed hard substrate.

The canyon-floor sand environment in the shallow depth zone $(<300 \mathrm{~m})$ is relatively depauperate (figs. 30-38). Mobile species typically associated with this sedimentary regime include the witch flounder, goosefish, and jonah crab. The sessile anemones Actinauge and Bolocera are relatively common, but they are restricted to isolated cobbles and boulders that are surrounded by rippled and duned sand (fig. 37). Semiconsolidated sandy silt is exposed sporadically in the troughs between dunes, but the shifting sands make it an unfavorable habitat for burrowing organisms. Although the sedimentary environment is similar in the middle depth zone (>300 $\mathrm{m})$, species abundance and diversity increase due to the presence of the red crab and demersal fish such as the long-nosed eel and the common grenadier (fig. 32).

\section{SUMMARY}

The northern part of Oceanographer Canyon varies in width from 2.7 to $5.5 \mathrm{~km}$ and in depth from 210 to $700 \mathrm{~m}$ as it meanders across the southeastern edge of Georges Bank. The canyon head exhibits numerous side canyons, some of which do not extend down to the canyon floor. The walls of the main canyon are undulatory and less deeply dissected. The steepness of the canyon walls ranges from 5 to $20^{\circ}$, but reaches an average of $38^{\circ}$ in two areas; at about $40^{\circ} 24.5^{\prime} \mathrm{N}$ where vertical outcrops of semiconsolidated sandy silt are present on the lower east wall, and in the canyon head where siltstone outcrops and talus form steep slopes in the western arm.

Since the last rise in sea level, Georges Bank has been isolated from continental sediment sources by the Gulf of Maine, and the sea floor in the canyon and on the surrounding shelf exhibits distinctive sediment types that are related to modern and glacial depositional environments.

The canyon walls and floor are underlain by semiconsolidated sandy silt or mud of Pleistocene age that is exposed on the lower walls but covered on the upper walls and canyon rim by unconsolidated sediments. The sandy silt is very similar texturally to modern sediments now accumulating in such diverse environments as the shelf south of Martha's Vineyard and the slope and rise seaward of the canyon. Gravel and gravel pavements, including cobbles and boulders, are concentrated in several areas of the canyon rim. 
The semiconsolidated sandy silt and the gravel probably were deposited during a glacial period, the silt from outwash and the gravel from ice floes that stranded around the canyon margin.

In the canyon head, there is an extensive exposure of dolomitic siltstone at $150 \mathrm{~m}$ depth and an accumulation of talus on the walls below. The siltstone appears to be an indurated form of the sandy silt, and it is responsible for the steepness of the canyon walls.

Ot.rer sediment types are mobile, unconsolidated sands that have resulted from the transport of glacially derived shelf sands into the canyon by currents. On the canyon rim, shelf sand is mixed with immobile gravel deposits. On the upper canyon walls, the sand is mixed with sediment burrowed from the underlying sandy silt to form deposits of silty sand. Upon reaching the canyon floor, the silty sand is reworked by currents into dunes, and the clay and silt are winnowed out and transported out of the canyon.

The benthic canyon fauna varies in composition with substrate type and water depth. Two faunal depth zones are present in this part of the canyon, the break occurring at about $300 \mathrm{~m}$. In general, faunal diversity is highest on the gravel, gravel pavements, and siltstone outcrops on the canyon rim, and the greatest biomass per unit area occurs on the siltstone outcrops and talus in the canyon head. In contrast, low faunal diversity and the lowest biomass occur in the duned sands of the canyon floor.

Benthic organisms are responsible to a large extent for the erosion and reworking of the canyon sediment. Extensive burrowing in the semiconsolidated sandy silt substratum loosens silt and clay particles that apparently are transported downcanyon in suspension, or are first mixed with the thin layer of overlying sand and then separated by winnowing after the sands reach the canyon floor. Burrowing produces new habitats in the form of pueblo village structures, and it also weakens the sea floor, causing small-scale collapses that result in the formation of vertical outcrops and in increased instability.

\section{REFERENCES CITED}

Bothner, M.H., Spiker, E.C., Johnson, P.P., Rendigs, R.R., and Aruscavage, P.J., 1981, Geochemical evidence for modern sediment accumulation on the Continental Shelf off southern New England: Journal of Sedimentary Petrology, v. 51, p. 281-292.

Butman, B., Beardsley, R.C., Magnell, B., Frye, D., Vermersch, J.A., Schlitz, R., Limeburner, R., Wright, W.R., and Noble, M.A., 1982, Recent observations on the mean circulation on Georges Bank: Journal of Physical Oceanography, v. 12, p. 569-591.

Cooper, R.A., Uzmann, J.R., Hulbert, A., and Shephard, A., 1983, Georges Bank and submarine canyon living resources and habitat baselines in oil and gas drilling areas: Manned Undersea Research and Technology Program, FY 1982 Northeast Monitoring Program Report, Northeast Fisheries Center, National Marine Fisheries Service, Woods Hole, MA, $42 \mathrm{p}$.

Deuser, W.G., 1970 , Extreme ${ }^{13} \mathrm{C} /{ }^{12} \mathrm{C}$ variations in Quaternary dolomites from the continental shelf: Earth and Planetary Science Letters, v. 8, p. 118-124.
Folger, D.W., Butman, B., Knebel, H.J.. and Sylwester, R.J., 1978. Environmental hazards on the Atlantic Outer Continental Shelf of the United States: Offshore Technology Conference Proceedings, v. 4, p. 2293-2306.

Folk, R.L., 1980, Petrology of Sedimentary Rocks: Hemphill Publishing Co., Austin, Texas, $82 \mathrm{p}$.

Hathaway, J.C., ed., 1971, Data file, Continental Margin Program, Atlantic Coast of the United States, v. 2, Sample collection and analytical data: Woods Hole Oceanographic Institution Ref. no. 71-75, $496 \mathrm{p}$.

Schlee, John, 1966, A modified Woods Hole rapid sediment analyzer: Journal of Sedimentary Petrology, v. 36, p. 403-413.

1973. Atlantic Continental Shelf and Slope of the United States - sediment texture of the northeastern part: U.S. Geological Survey Professional Paper 529-L, 64 p.

Stetson, H.C., 1949, The sediments and stratigraphy of the east-coast continental margin; Georges Bank to Norfolk Canyon: Massachusetts Institute of Technology and Woods Hole Oceanographic Institution Papers in Physical Oceanography and Meteorology, v. 11, no. 2, 60 p.

Twichell, D.C., MeClennen, C.E., and Butman. B., 1981, Morphology and processes associated with the accumulation of the fine-grained sediment deposit on the southern New England shelf: Journal of Sedimentary Petrology, v. 51, p. 269280.

Uchupi, Elazar, 1965, Map showing relation of land and submarine topography. Nova Scotia to Florida: U.S. Geological Survey Miscellaneous Geologic Investigations Map I-451, 3 sheets, scale $1: 1,000,000$.

Valentine, P.C., Uzmann, J.R., and Cooper, R.A., $1980 \mathrm{a}$, Geology and biology of Oceanographer submarine canyon: Marine Geology, v. 38, p. 283-312.

$1980 \mathrm{~b}$, Geologic and biologic observations in Oceanographer Submarine Canyon-descriptions of dives aboard the research submersibles Alvin (1967, 1978) and Nekton Gamma (1974): U.S. Geological Survey Open-File Report 80-76, 36 p. 
$\bullet$
$\bullet$
$\bullet$ 